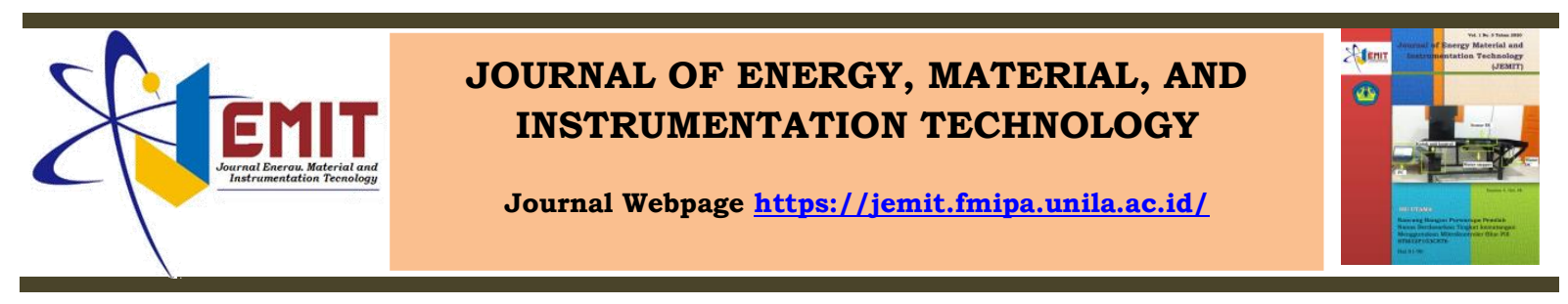

\title{
Analisis Potensi Energi Listrik Pikohidro dari Sumber Air Pegunungan Serta Upaya Peningkatan Daya Listrik dengan Memanfaatkan Rangkaian Joule Thief
}

\author{
Ahmad Badrus Soleh, Amir Supriyanto*, Gurum Ahmad Pauzi, dan Arif Surtono \\ Jurusan Fisika, Universitas Lampung, Bandar Lampung, Indonesia, 35141
}

\begin{tabular}{|c|c|}
\hline Article Information & Abstract \\
\hline $\begin{array}{l}\text { Article history: } \\
\text { Received October } 24^{\text {th }}, 2020 \\
\text { Received in revised form } \\
\text { October } 26^{\text {th }}, 2020 \\
\text { Accepted November } 17^{\text {th }} \\
2020\end{array}$ & $\begin{array}{l}\text { The research about picohydro power plant system has been developed in recent } \\
\text { years. However, there is a problem in output power when using too small water } \\
\text { debit on it. Output power can improved with a generator module and joule thief } \\
\text { module. The generator module uses a turbine that the diameter is } 4 \mathrm{~cm} \text { to drive a } \\
\text { permanent magnet generator while the joule thief module consists of a charger } \\
\text { controller to control charging process of battery, } 3200 \mathrm{mAh} \text { lithium-ion battery for } \\
\text { storing electric power generated by the generator and a joule thief circuit to increase } \\
\text { the electrical power that stored in the battery. This device has been tested by using }\end{array}$ \\
\hline $\begin{array}{l}\text { Keywords: } \\
\text { picohydro, Joule Thief, } \\
\text { Power }\end{array}$ & $\begin{array}{l}7 \text { variations of water debit that is } 0.06 \text { liters/second, } 0.066 \text { liters/second, } 0.071 \\
\text { liters/second, } 0.077 \text { liters/second, } 0.093 \text { liters/second, } 0.138 \text { liters/second, and } \\
0.14 \text { liters/second. The results showed that the increasement of power generated } \\
\text { when water debit are increased. The maximum power generated in this power } \\
\text { generation system is } 7.75 \mathrm{~W} \text { and its able to supply power for LED lights } 220 \mathrm{~V} 3 \mathrm{~W} \\
\text { for } 165 \text { minutes. }\end{array}$ \\
\hline
\end{tabular}

\begin{tabular}{|c|c|}
\hline Informasi Artikel & Abstrak \\
\hline $\begin{array}{l}\text { Proses artikel: } \\
\text { Diterima } 24 \text { Oktober } 2020 \\
\text { Diterima dan direvisi dari } \\
26 \text { Oktober } 2020 \\
\text { Accepted } 17 \text { November } 2020\end{array}$ & $\begin{array}{l}\text { Penelitian mengenai sistem pembangkit listrik pikohidro banyak dikembangkan } \\
\text { dalam beberapa tahun terakhir. Namun, dalam proses penelitian sistem pembangkit } \\
\text { listrik pikohidro masih memiliki kendala pada daya yang dihasilkan ketika debit air } \\
\text { yang digunakan sangat kecil. Daya listrik yang dihasilkan dapat ditingkatkan } \\
\text { dengan modul generator dan modul joule thief. Modul generator menggunakan turbin } \\
\text { dengan diameter } 4 \mathrm{~cm} \text { untuk menggerakkan generator magnet permanen sedangkan } \\
\text { modul joule thief terdiri dari charger controller TP4056 sebagai pengendali penaisian }\end{array}$ \\
\hline $\begin{array}{l}\text { Kata kunci: } \\
\text { Pikohidro, Joule Thief, Daya }\end{array}$ & $\begin{array}{l}\text { baterai, baterai lithium-ion } 3200 \mathrm{mAh} \text { sebagai penyimpan daya listrik yang } \\
\text { dihasilkan generator dan rangkaian joule thief untuk meningkatkan daya listrik yang } \\
\text { tersimpan pada baterai. Pengujian dilakukan dengan menggunakan } 7 \text { variasi debit } \\
\text { air yaitu } 0,06 \text { liter/detik, O,066 liter/detik, O,071 liter/detik, O,077 liter/detik, O,093 } \\
\text { liter/detik, O,138 liter/detik, dan O,14 liter/detik. Hasil penelitian menunjukkan } \\
\text { adanya kenaikan daya yang dihasilkan setiap bertambahnya debit air. Daya } \\
\text { maksimal yang dihasilkan pada sistem pembangkit listrik ini sebesar } 7,75 \mathrm{~W} \text { dan } \\
\text { mampu untuk menyuplai daya untuk lampu LED } 220 \mathrm{~V} 3 \mathrm{~W} \text { selama } 165 \text { menit. }\end{array}$ \\
\hline
\end{tabular}

\section{Pendahuluan}

Pemanfaatan energi listrik telah dilakukan di berbagai bidang seperti pada bidang sosial, ekonomi,dan kesehatan. Seiring dengan perkembangan zaman kebutuhan energi listrik di Indonesia terus meningkat, hal ini disebabkan oleh pertambahan jumlah penduduk dan pertumbuhan ekonomi yang terus meningkat setiap tahunnya. Menurut proyeksi Badan Pusat Statistik (BPS), jumlah penduduk di Indonesia pada tahun 2018 adalah \pm 265 juta jiwa (Badan Pusat Statistik, 2017). Berdasarkan data ketenagalistrikan nasional tahun 2017 total penyediaan tenaga listrik pada akhir tahun 2017 sebesar 254.657 GWh yang terdiri dari produksi listrik PLN sebesar 181.422 GWh dan pembelian sebesar 73.234 GWh, sedangkan jumlah konsumsi tenaga listrik seluruh 
Ahmad Badrus Soleh, Amir Supriyanto*, Gurum Ahmad Pauzi, dan Arif Surtono, 2020, Analisis Potensi Energi Listrik Pikohidro dari Sumber Air Pegunungan Serta Upaya Peningkatan Daya Listrik dengan Memanfaatkan Rangkaian Joule Thief, Jurnal of Energy, Material, and Instrumentation Technology, Vol. 1 No. 3, 2020

Indonesia adalah sebesar 267.453 GWh. Sampai saat ini, energi listrik di Indonesia masih disuplai oleh bahan bakar fosil berupa batubara dengan persentase 49,69\% (Kementrian Energi dan Sumber Daya Mineral, 2017). Berdasarkan data tersebut, di Indonesia masih terdapat kekurangan dalam suplai tenaga listrik serta pengembangan energi alternatif. Sedangkan cadangan batubara, gas, dan panas bumi di alam semakin berkurang setiap tahunnya sehingga akan berpengaruh terhadap ketersediaan tenaga listrik.

Berbagai upaya dilakukan oleh pemerintah dalam mengatasi permasalahan kekurangan suplai tenaga listrik terutama di daerah terpencil yaitu dengan meningkatkan pengembangan energi listrik yang bersumber pada energi terbarukan, salah satu sumber energi terbarukan yang sangat potensial di Indonesia yaitu energi air. Menurut penelitian yang telah dilakukan oleh Erinofiardi dkk (2017), daerah pegunungan di Indonesia memiliki potensi sumber daya air yang melimpah sehingga dapat dimanfaatkan sebagai energi penggerak untuk menghasilkan energi listrik. Pemanfaatan energi air menjadi energi listrik dapat dilakukan dengan menggunakan teknologi pikohidro. Sistem pembangkit ini baik digunakan pada daerah pegunungan yang memiliki aliran air yang kecil sebagai sumber energinya sehingga dapat diterapkan untuk penyediaan tenaga listrik ke rumah-rumah warga yang tidak terjangkau jaringan listrik PLN. Secara teknis, tenaga listrik diperoleh dengan proses konversi energi dari energi mekanik air menjadi energi listrik (Zainuddin dkk, 2009; Risnandar dan Novrinaldi, 2011; Khomsah dan Zulairi, 2015).

Proses perubahan energi mekanik air menjadi energi listrik memanfaatkan prinsip GGL induksi Faraday. Air sebagai energi penggerak akan memutar turbin yang kemudian akan menggerakkan magnet ataupun kumparan sehingga gerakan tersebut akan menghasilkan gaya gerak listrik (Giancoli, 2001). Pemanfaatan aliran air berdebit kecil sebagai pembangkit listrik telah dilakukan oleh Warsito dkk (2010) menggunakan mini turbin tipe Francis dan generator magnet permanen 3 pasang kutub yang mempunyai kecepatan putar optimal 2400 rpm (rotation per minute). Keluaran dari generator tersebut berupa tegangan dan arus bolak balik dengan tegangan yang dihasilkan sebesar 12/15 V dan kapasitas daya $6 \mathrm{~W}$. Akan tetapi daya listrik yang dihasilkan sangat bergantung dari debit air yang mengalir, sehingga dibutuhkan sebuah perangkat yang dapat memaksimalkan daya listrik yang dihasilkan. Joule thief dipandang sebagai pilihan yang tepat untuk memaksimalkan daya listrik dari sumber energi listrik yang kecil. Pada dasarnya rangkaian joule thief merupakan rangkaian yang digunakan untuk merubah tegangan DC (Direct Current) menjadi tegangan AC (Alternating Current) yang menggunakan prinsip transformator sebagai penaik tegangan dan transistor sebagai osilator sehingga dihasilkan tegangan yang berosilasi (tegangan AC) (Manfaluthy, 2018).

Berdasarkan latar belakang yang telah dijelaskan, maka dalam penelitian ini akan membahas dan merancang sebuah Pembangkit Listrik Tenaga Pikohidro (PLTPH) menggunakan aliran air pegunungan yang dialirkan dari pipa PVC dengan debit air kecil dan memanfaatkan rangkaian joule thief untuk memaksimalkan daya yang dihasilkan dari generator dengan variasi serta debit air.

\section{Metode Penelitian}

Penelitian ini dilakukan dengan memisahkan rancangan penelitian ke dalam 4 tahap. Diantaranya ialah mencari bahan literatur yang berhubungan dengan teori tentang turbin air, teori tentang generator, teori fluida, aplikasi rangkaian joule thief dan mempelajari parameter-parameter utama yang akan diimplementasikan dalam pembuatan alat. Selanjutnya dilakukan perancangan sistem pada turbin dan generator. Kemudian dilanjutkan dengan perakitan komponen menjadi rangkaian penyearah, rangkaian joule thief dan modul charger controller sebagai pengendali pengisian pada baterai. Setelah itu, dilakukan perakitan alat secara keseluruhan kemudian melakukan pengambilan data. Tahapan tersebut lebih rinci dapat dilihat pada Gambar 1.

\subsection{Perancangan Turbin dan Generator}

Turbin air ini terdiri dari sudu, as, dan casing turbin. Sudu dan casing turbin menggunakan bahan plastik sehingga daya putar turbin menjadi ringan, sedangkan pada as menggunakan bahan besi dengan diameter $0,3 \mathrm{~cm}$ dan panjang $2,5 \mathrm{~cm}$. Jumlah sudu yang digunakan sebanyak 24 buah dan derajat sudu nya $45^{\circ}$ serta ketebalan sudu $0,125 \mathrm{~cm}$. Sudu dengan panjang $1,2 \mathrm{~cm}$ dan lebar $0,5 \mathrm{~cm}$ disusun melingkar dengan jarak yang sama. Diameter dalam turbin yaitu $3 \mathrm{~cm}$ dan diameter keseluruhan turbin yaitu $4 \mathrm{~cm}$. Rancangan turbin secara keseluruhan dapat dilihat pada Gambar 2.

Generator terdiri dari magnet yang telah terpasang pada turbin, dan stator yang telah diberi kawat lilitan. Pada stator digunakan kawat lilitan dengan diameter $0,1 \mathrm{~mm}$ dengan jumlah 150 lilitan setiap kiliknya kemudian dipasang pada casing turbin seperti pada Gambar 3. 


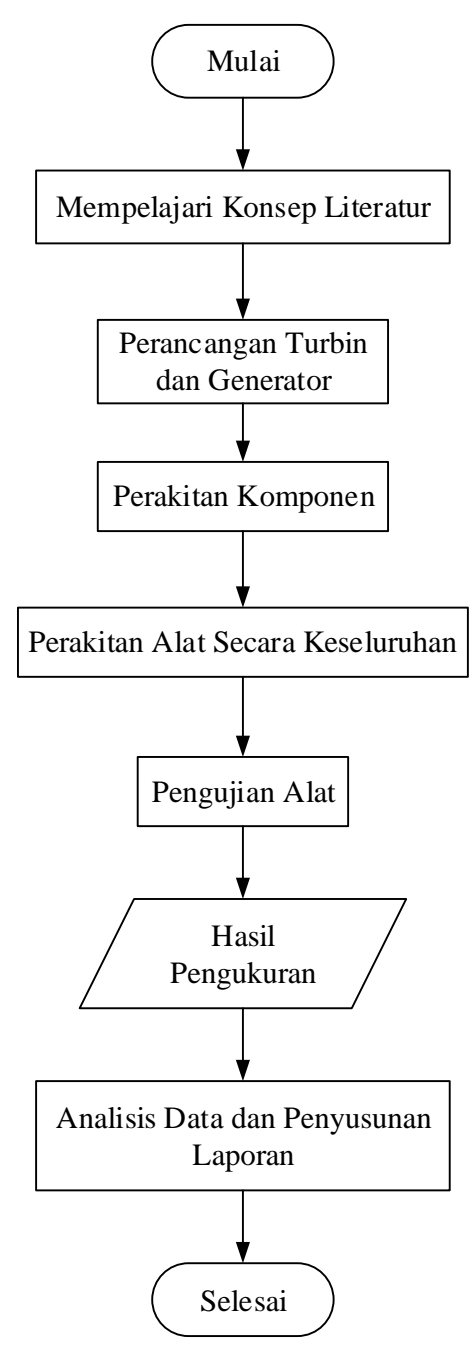

Gambar 1. Diagram Blok

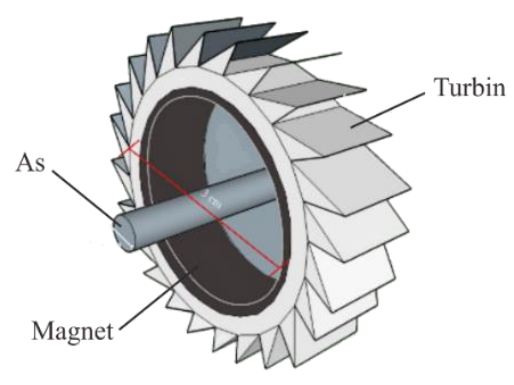

Gambar 2. Rancangan turbin

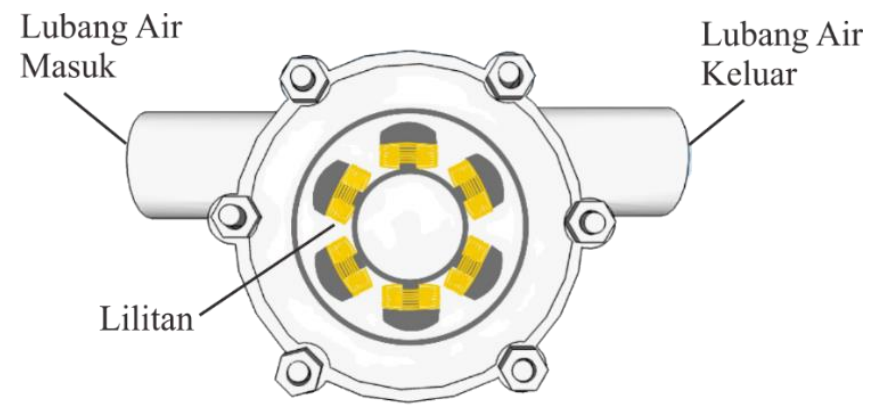

Gambar 3. Kumparan dalam casing turbin

\subsection{Perakitan Komponen}

Rangkaian penyearah digunakan untuk mengubah tegangan keluaran dari generator yang berupa tegangan bolak-balik (AC) menjadi tegangan searah (DC). Rangkaian ini terdiri dari beberapa komponen yaitu 6 buah dioda, 2 buah kapasitor, dan 1 buah resistor. Seluruh komponen menggunakan tipe SMD (Surface-mount Device). Hal ini bertujuan agar rangkaian yang dihasilkan memiliki ukuran yang kecil sehingga dapat diletakkan dalam casing turbin. Skema rangkaian penyearah dapat dilihat pada Gambar 4 dan Gambar 5. 


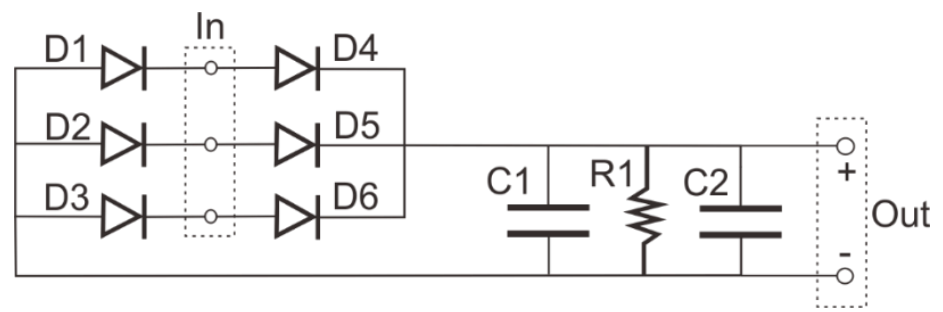

Gambar 4. Skema rangkaian penyearah

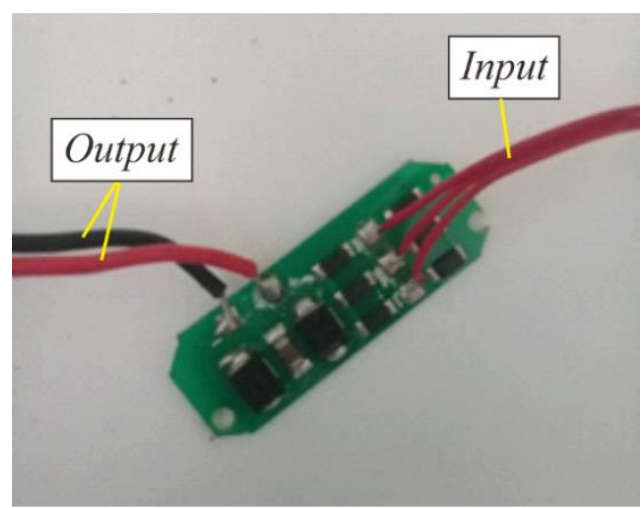

Gambar 5. Rangkaian penyearah

Sebagai pengendali dalam pengisian baterai pada penelitian ini menggunakan modul charger controller TP4056. Modul ini dipilih karena mudah dalam penggunaan serta harganya yang terjangkau. Tegangan masukan untuk modul ini yaitu berkisar antara 4-8 volt dengan arus masukan maksimal 1,2 A.Skema rangkaian dan bentuk modul charger controller TP4056 dapat dilihat pada Gambar 6 dan Gambar 7.

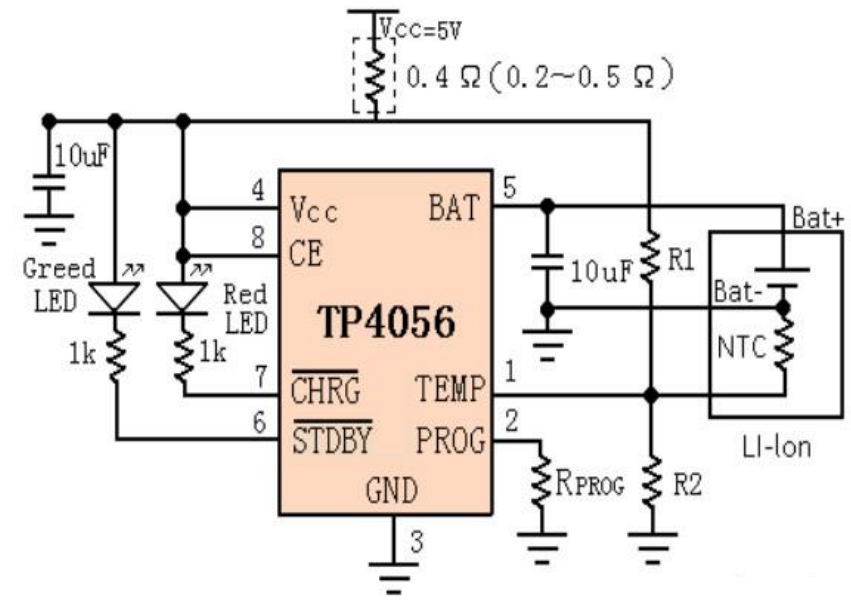

Gambar 6. Skema modul charger controller TP4056

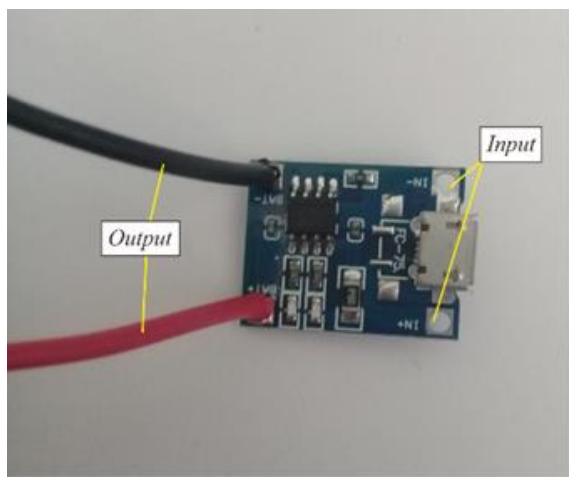




\section{Gambar 7. Modul charger controller TP4056}

Rangkaian joule thief pada alat ini digunakan untuk mengubah tegangan DC dari baterai menjadi tegangan AC kemudian dinaikkan tegangannya. Rangkaian ini terdiri dari 3 buah resistor yang masing-masing bernilai 10 Ohm, $220 \mathrm{Ohm}$, dan $330 \mathrm{Ohm}, 1$ buah transistor D822, 2 buah dioda IN4002, dan 1 buah kapasitor $1 \mathrm{nF}, 2$ buah kapasitor $47 \mu \mathrm{F}$, dan 1 buah transformator bekas charger handphone. Skema dan bentuk rangkaian joule thief dapat dilihat pada Gambar 8 dan Gambar 9.

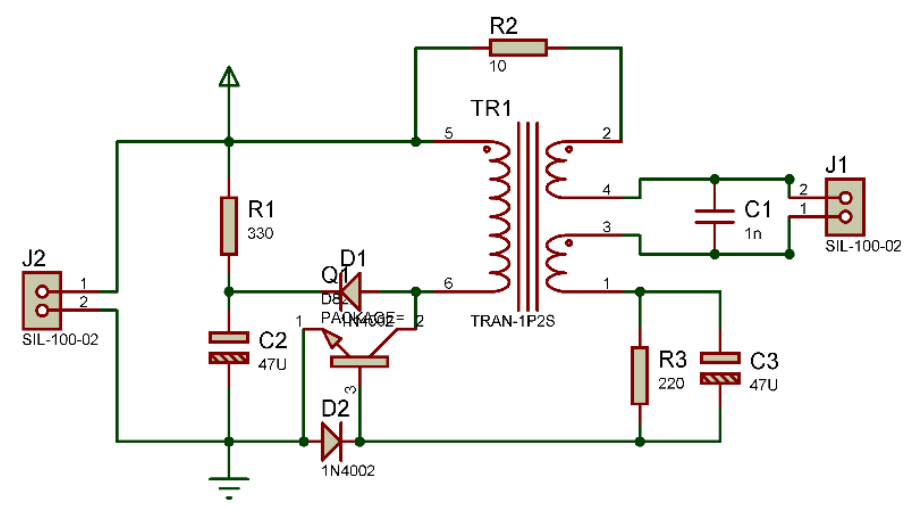

Gambar 8. Skema rangkaian Joule thief

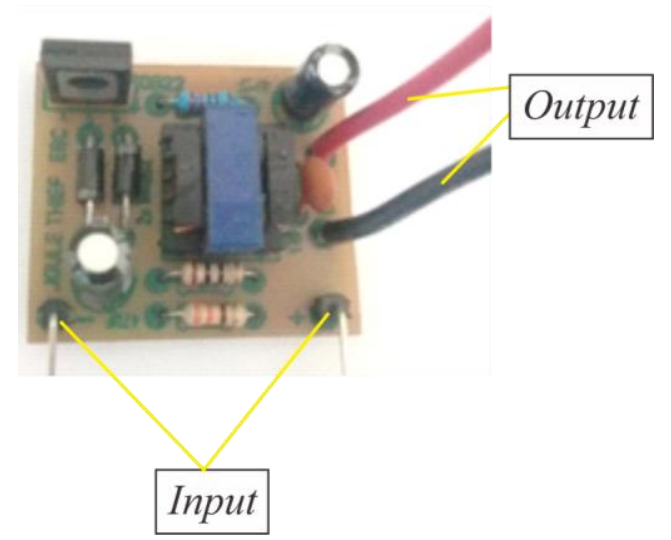

Gambar 9. Rangkaian joule thief

\subsection{Perakitan Alat Secara Keseluruhan}

Setelah seluruh alat selesai, kemudian dilakukan perakitan alat secara keseluruhan yang terdiri dari turbin dan generator, rangkaian penyearah, modul charger controller, dan rangkaian joule thief yang kemudian dihubungkan dengan beban berupa lampu LED 3 watt. Perakitan alat secara keseluruhan dapat dilihat pada Gambar 10.

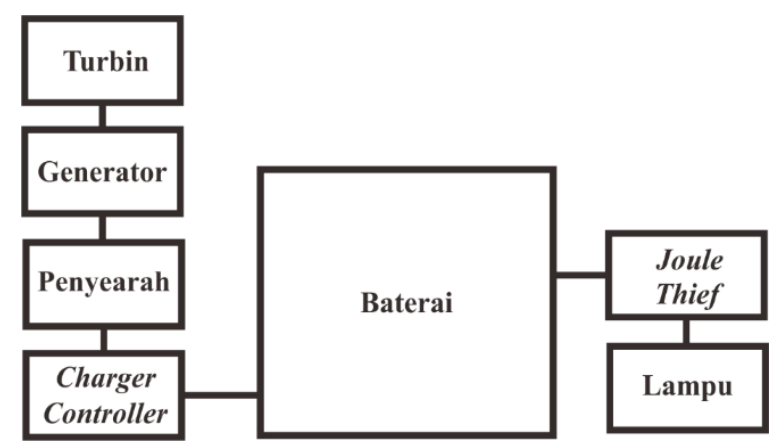

Gambar 10. Diagram blok alat 
Ahmad Badrus Soleh, Amir Supriyanto*, Gurum Ahmad Pauzi, dan Arif Surtono, 2020, Analisis Potensi Energi Listrik Pikohidro dari Sumber Air Pegunungan Serta Upaya Peningkatan Daya Listrik dengan Memanfaatkan Rangkaian Joule Thief, Jurnal of Energy, Material, and Instrumentation Technology, Vol. 1 No. 3, 2020

\section{Hasil dan Pembahasan}

\subsection{Realisasi Alat}

Penelitian analisis potensi energi listrik pikohidro dari sumber air pegunungan serta upaya peningkatan daya listrik dengan memanfaatkan rangkaian joule thief terdiri dari perancangan mekanik dan perancangan elektrik. Perancangan mekanik yaitu pembuatan modul generator pikohidro dan perancangan elektrik yaitu pembuatan modul joue thief. Modul generator yang telah dibuat terdiri dari beberapa bagian seperti ditunjukkan pada Gambar 11. Pipa PVC yang digunakan sebagai tempat mengalirnya air memiliki diameter $1 / 2$ inch dengan kran air sebagai pengatur debitnya. Bagian belakang modul generator terdapat magnet yang menempel pada turbin bagian dalam serta as turbin. Magnet akan berputar seiring dengan berputarnya turbin. Kumparan dan rangkaian penyearah diletakkan pada bagian dalam casing modul generator. Pemasangan ini bertujuan untuk mencegah air masuk kedalam kumparan. Ketika aliran air masuk dan menerpa turbin, maka turbin akan berputar beserta magnet. Putaran magnet di sekeliling kumparan mengakibatkan perubahan intensitas medan magnet di sekitar kumparan dan akan menghasilkan listrik.

Listrik yang dihasilkan oleh generator ini berupa arus AC yang disalurkan untuk pengisian baterai, sehingga diberikan rangkaian penyearah untuk mengubah arus AC yang dihasilkan menjadi arus DC. Arus DC kemudian disalurkan ke modul joule thief yang telah dibuat seperti pada Gambar 12.

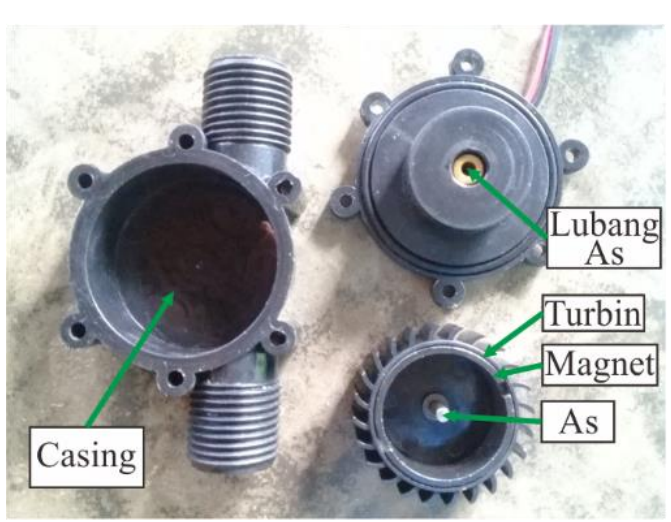

(a)

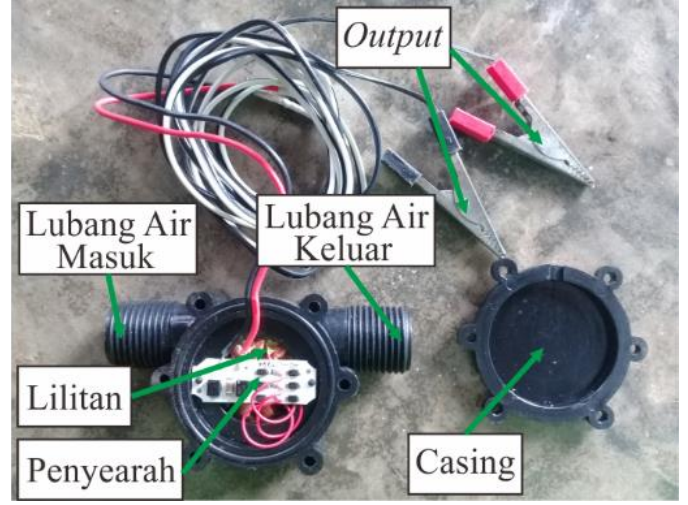

(b)

Gambar 11. (a) Modul generator tampak depan; (b) modul generator tampak belakang

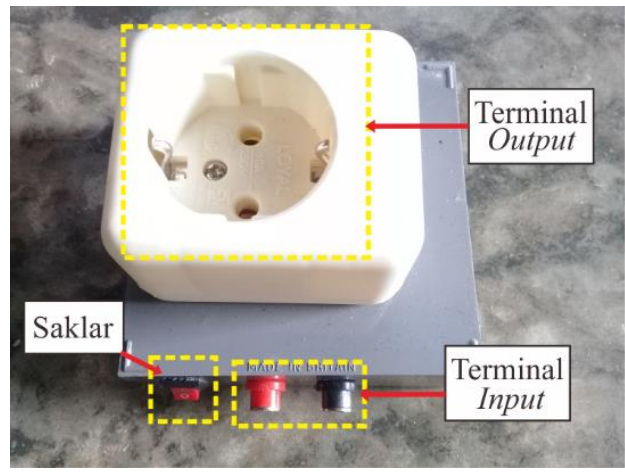

(a)

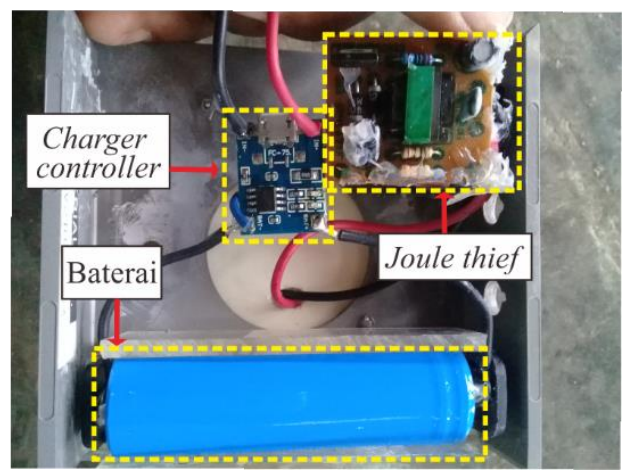

(b)

Gambar 12. (a) Modul joule thief tampak depan; (b) Modul joule thief tampak belakang

Modul joule thief yang dibuat memiliki dimensi $9 \mathrm{~cm}$ x $9 \mathrm{~cm} \times 7,5 \mathrm{~cm}$ dengan box yang terbuat dari bahan plastik. Bagian luar modul terdapat dua lubang terminal yang berfungsi sebagai output yang dapat dihubungkan dengan lampu. Dua buah terminal berwarna merah dan hitam di bagian samping berfungsi sebagai terminal penghubung antara modul generator dan charger controller pada modul joule thief dalam proses pengisian baterai. Saklar pada bagian samping berfungsi sebagai pemutus arus listrik dari baterai yang masuk ke rangkaian joule thief.

Terdapat beberapa komponen pada bagian modul yang terdiri dari modul charger controller TP4605, baterai lithium-ion 16850, dan rangkaian joule thief. Tegangan yang masuk ke modul charger controller TP4605 berasal dari listrik yang dihasilkan oleh generator setelah mengalami proses penyearahan. Keluaran dari modul charger controller kemudian dihubungkan ke baterai lithium-ion 16850 dengan kapasitas 3200 mAh. Baterai pada modul joule thief berfungsi sebagai penyimpanan listrik dari generator. 


\subsection{Analisis Data}

1. Tegangan yang Dihasilkan Generator

Pengukuran tegangan yang dihasilkan oleh generator dengan 7 variasi debit air dimana setiap debit air dilakukan 5 kali pengulangan. Pemilihan besar debit air untuk mengetahui besar tegangan yang dihasilkan dari generator. Pengukuran dilakukan dengan menghubungkan multimeter pada output generator yang telah melalui proses penyearahan seperti pada Gambar 13. Dari pengukuran yang dilakukan diperoleh data tegangan seperti pada Tabel 1.

Tabel 1. Hasil pengukuran tegangan generator

\begin{tabular}{cccccccc}
\hline \multirow{2}{*}{ Pengulangan ke- } & \multicolumn{7}{c}{ Debit Air (liter/detik) } \\
\cline { 2 - 8 } & $\mathbf{0 , 0 6}$ & $\mathbf{0 , 0 6 6}$ & $\mathbf{0 , 0 7 1}$ & $\mathbf{0 , 0 7 7}$ & $\mathbf{0 , 0 9 3}$ & $\mathbf{0 , 1 3 8}$ & $\mathbf{0 , 1 4}$ \\
\hline 1 & $8,43 \mathrm{~V}$ & $9,06 \mathrm{~V}$ & $9,58 \mathrm{~V}$ & $10,18 \mathrm{~V}$ & $11,12 \mathrm{~V}$ & $11,85 \mathrm{~V}$ & $11,99 \mathrm{~V}$ \\
2 & $8,45 \mathrm{~V}$ & $9,05 \mathrm{~V}$ & $9,59 \mathrm{~V}$ & $10,17 \mathrm{~V}$ & $11,11 \mathrm{~V}$ & $11,84 \mathrm{~V}$ & $12 \mathrm{~V}$ \\
3 & $8,44 \mathrm{~V}$ & $9,07 \mathrm{~V}$ & $9,57 \mathrm{~V}$ & $10,18 \mathrm{~V}$ & $11,14 \mathrm{~V}$ & $11,86 \mathrm{~V}$ & $12,01 \mathrm{~V}$ \\
4 & $8,46 \mathrm{~V}$ & $9,1 \mathrm{~V}$ & $9,62 \mathrm{~V}$ & $10,16 \mathrm{~V}$ & $11,13 \mathrm{~V}$ & $11,85 \mathrm{~V}$ & $12 \mathrm{~V}$ \\
5 & $8,42 \mathrm{~V}$ & $9,07 \mathrm{~V}$ & $9,59 \mathrm{~V}$ & $10,17 \mathrm{~V}$ & $11,12 \mathrm{~V}$ & $11,87 \mathrm{~V}$ & $12 \mathrm{~V}$ \\
Rata-rata & $\mathbf{8 , 4 4} \mathbf{~ V}$ & $\mathbf{9 , 0 7} \mathbf{~ V}$ & $\mathbf{9 , 5 9} \mathbf{~ V}$ & $\mathbf{1 0 , 1 7} \mathbf{~ V}$ & $\mathbf{1 1 , 1 2} \mathbf{~ V}$ & $\mathbf{1 1 , 8 5 ~ V}$ & $\mathbf{1 2} \mathbf{~ V}$ \\
\hline
\end{tabular}

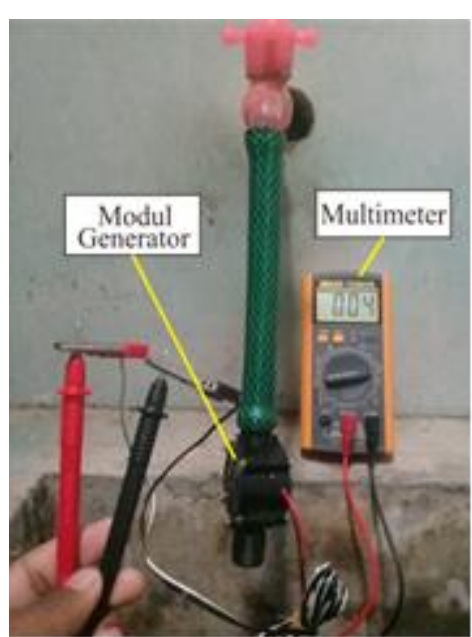

Gambar 13. Pengukuran tegangan generator

Tegangan yang dihasilkan generator pada setiap debit air mengalami fluktuasi yang cukup kecil berkisar antara 0,01 V-0,04 V setiap pengulangan pengukuran dilakukan. Sedangkan pada keseluruhan variasi debit air, tegangan yang dihasilkan generator mengalami perubahan yang signifikan. Hal ini terjadi karena ketika debit air berubah maka kecepatan air juga turut berubah sehingga menyebabkan adanya perubahan kecepatan pada turbin. Perubahan kecepatan turbin mengakibatkan perubahan fluks magnetik pada generator yang berpengaruh pada tegangan yang dihasilkan sesuai dengan Persamaan 1.

$$
\varepsilon=-N \frac{\Delta \phi}{\Delta t}
$$

dengan $\varepsilon$ beda potensial (V), $N$ jumlah lilitan, $\Delta \phi$ perubahan fluks magnetik (V/detik), dan $\Delta t$ perubahan waktu (detik).

\section{Tegangan dan Arus Pengisian Baterai}

Pengukuran tegangan pengisian dilakukan dengan menghubungkan multimeter ke kaki output modul generator secara paralel. Sedangkan pengukuran arus dilakukan dengan menghubungkan multimeter secara seri ke salah satu kaki output modul generator dan salah satu kaki input modul joule thief seperti pada Gambar 14. Pengukuran dilakukan pada setiap variasi debit air selama 5 jam dan dilakukan pengamatan setiap 10 menit. Hasil pengukuran tegangan dan arus pengisian baterai yang telah diolah dalam bentuk grafik seperti pada Gambar 15 dan Gambar 16. 


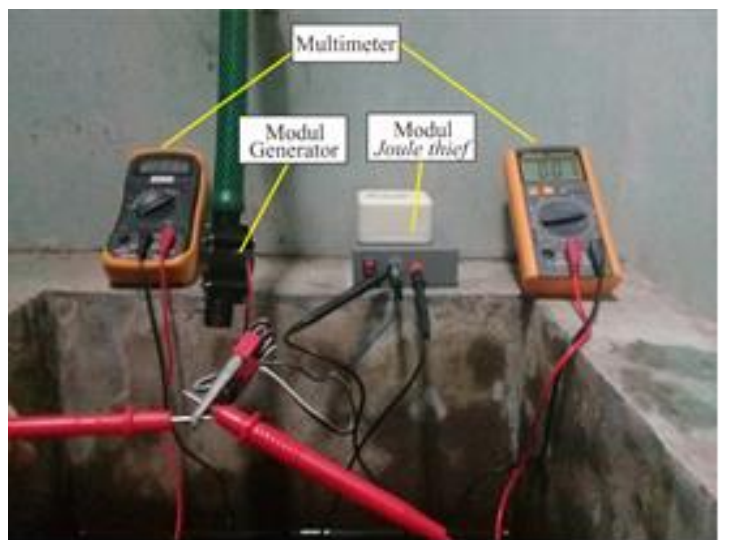

Gambar 14. Pengukuran tegangan dan arus pengisian baterai

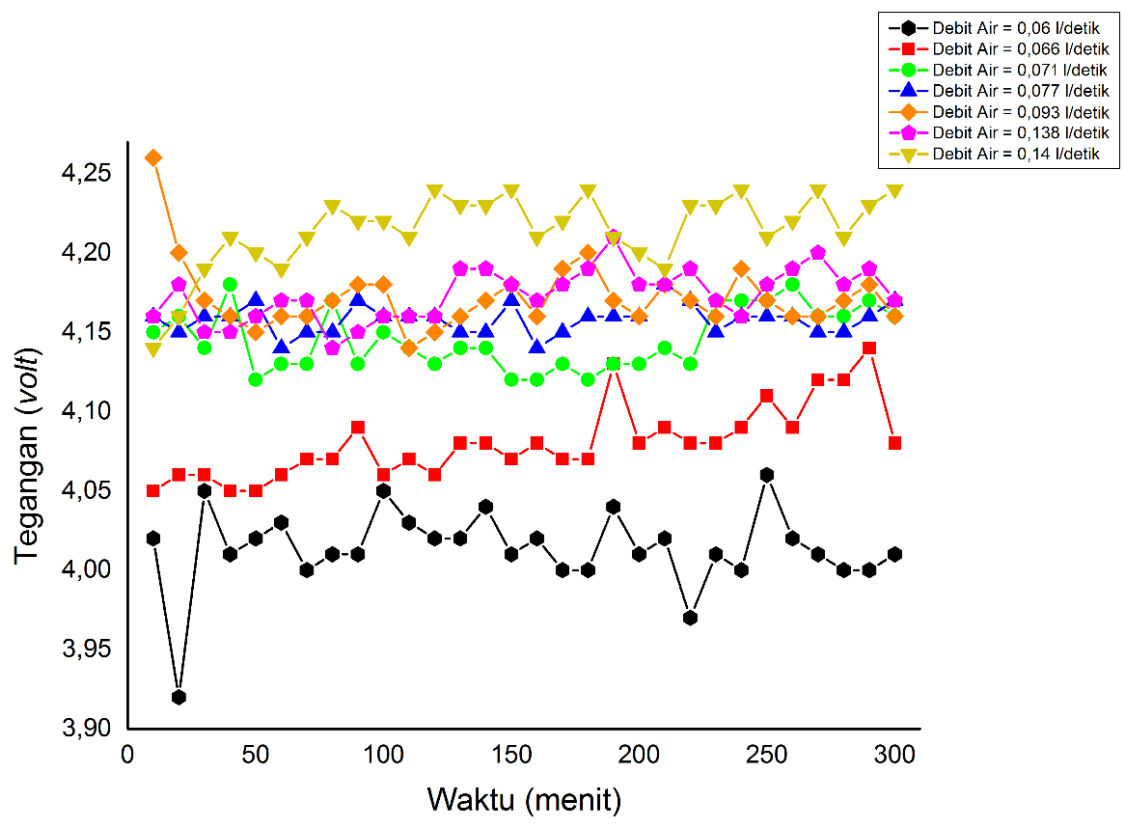

Gambar 15. Grafik hasil pengukuran tegangan pengisian baterai

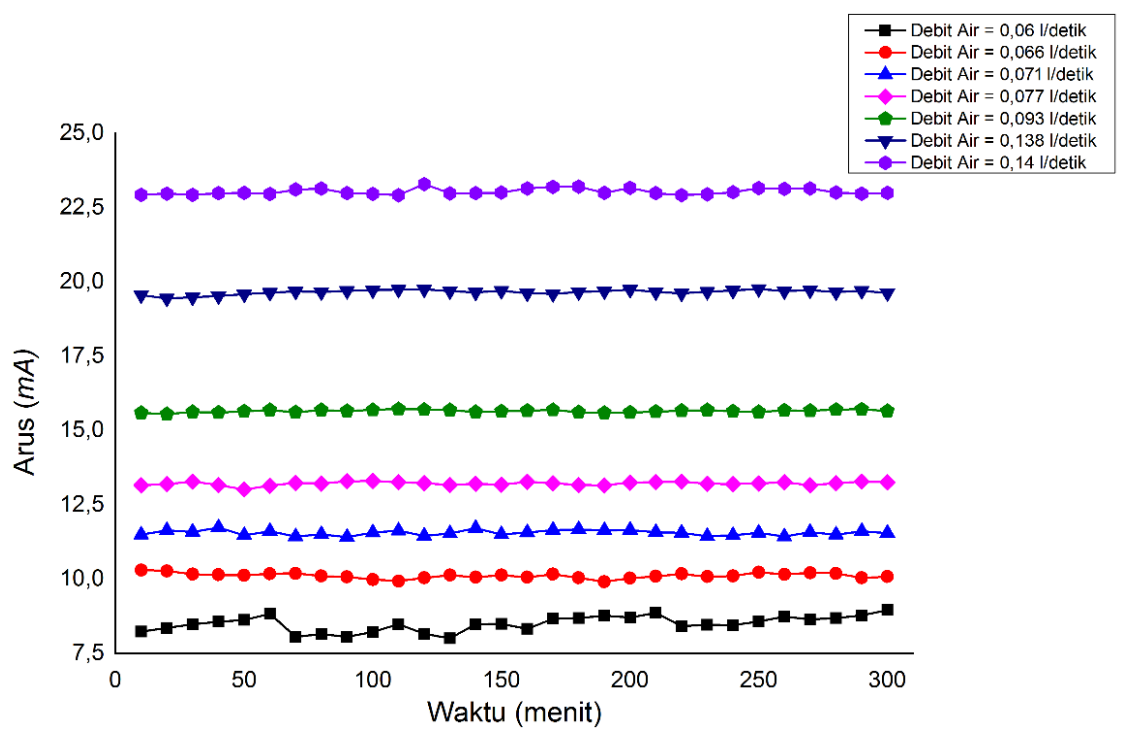

Gambar 16. Grafik hasil pengukuran arus pengisian baterai 
Gambar 15 merupakan grafik hasil pengukuran tegangan pengisian baterai selama 5 jam. Hasil pengukuran menunjukkan adanya fluktuasi hamper pada keseluruhan tegangan pengisian baterai di setiap variasi debit air. Fluktuasi tertinggi terletak pada debit air 0,06 liter/detik dan 0,093 liter/detik. Pada debit air 0,06 liter/detik, tegangan pengisian mengalami penurunan yang signifikan pada menit ke-20 kemudian naik kembali pada menit ke-30. Pada debit air 0,093 liter/detik, tegangan mengalami penurunan sampai pada menit ke-40 dan cenderung stabil pada menit berikutnya. Gambar 16 menunjukkan hasil pengukuran arus pengisian baterai pada setiap debit air. Arus pengisian yang diperoleh pada debit air 0,06 liter/detik mengalami kenaikan dan penurunan (tidak stabil) sehingga kurang baik digunakan untuk pengisian baterai. Pada debit air 0,066 liter/detik sampai dengan 0,14 liter/detik arus pengisian yang terukur cenderung stabil dan semakin besar setiap debit air diperbesar. Hal ini terjadi karena adanya perubahan kecepatan air yang menerpa kincir. Semakin besar kecepatan air yang menerpa kincir maka akan membuat kincir semakin berputar cepat dan menghasilkan tegangan dan arus yang lebih besar (Krishnastana dkk, 2018). Tegangan dan arus yang lebih besar akan meningkatkan daya pengisian sehingga proses pengisian pada baterai akan lebih cepat.

\section{Lama Waktu Pengisian Baterai}

Pengukuran lama waktu pengisian pada baterai dilakukan dengan mengukur tegangan pada baterai setiap 15 menit sekali dengan debit air yang masuk pada modul generator sebesar 0,14 liter/detik. Debit air tersebut dipilih karena merupakan debit air terbesar sehingga daya pengisian yang diperoleh akan maksimal. Hasil pengukuran yang diperoleh diolah dalam grafik seperti pada Gambar 17.

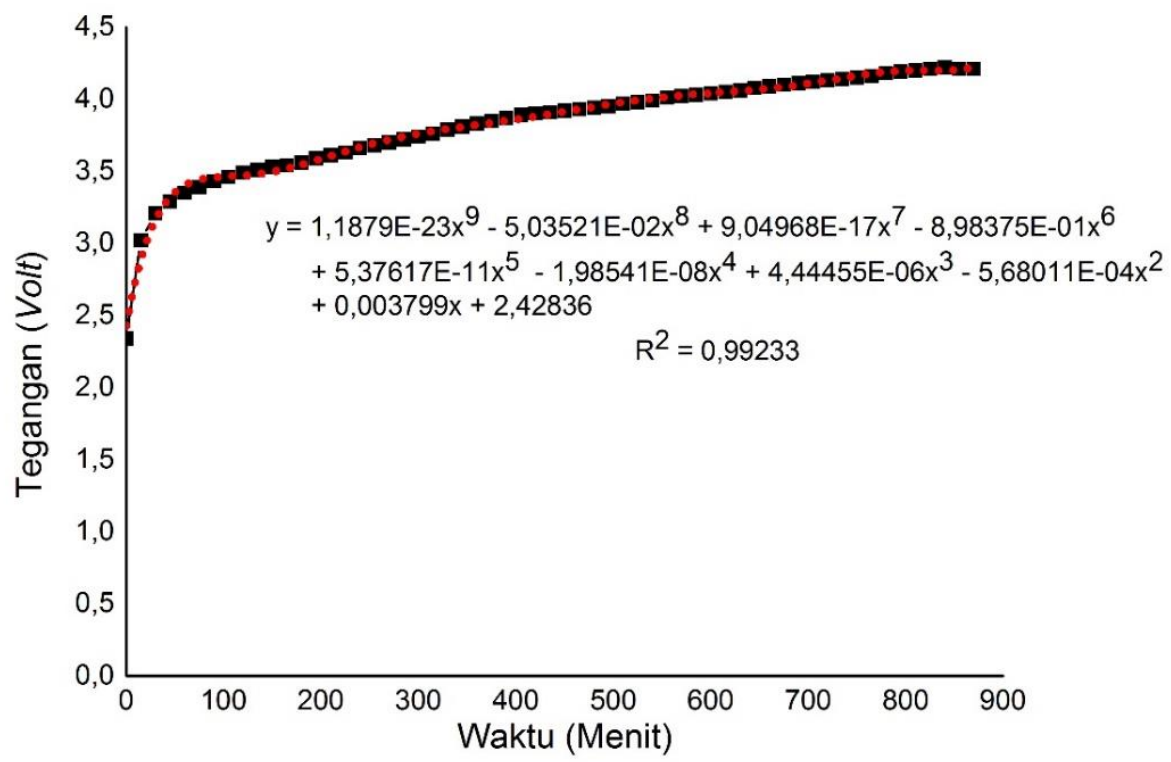

Gambar 17. Grafik hasil pengukuran lama waktu pengisian baterai

Gambar 17 menunjukkan tegangan awal pada baterai sebesar 2,34 V, terdapatnya tegangan awal ini menunjukkan bahwa baterai masih berfungsi dengan baik.Kemudian saat dilakukan pengisian terjadi peningkatan tegangan pada baterai seiring dengan bertambahnya waktu pengisian. Perubahan ini menunjukkan bahwa proses pengisian baterai sedang berlangsung. Setelah pengukuran pada menit ke-825, baterai telah terisi penuh dengan tegangan terukur sebesar 4,21 V.

4. Daya yang Dihasilkan Modul Joule Thief

Pengukuran daya yang dihasilkan oleh modul joule thief dilakukan setelah dilakukan 5 jam pengisian menggunakan debit air yang digunakan. Tegangan dan arus yang dihasilkan diukur menggunakan multimeter pada kaki output modul seperti pada Gambar 18. Tegangan dan arus yang terukur disubtitusikan dalam Persamaan 3.1 untuk mendapatkan nilai daya yang dihasilkan.Pengukuran juga dilakukan ketika baterai terisi penuh agar diketahui daya maksimal yang dapat dihasilkan oleh alat. Hasil daya yang diperoleh dalam bentuk grafik seperti pada Gambar 19. 


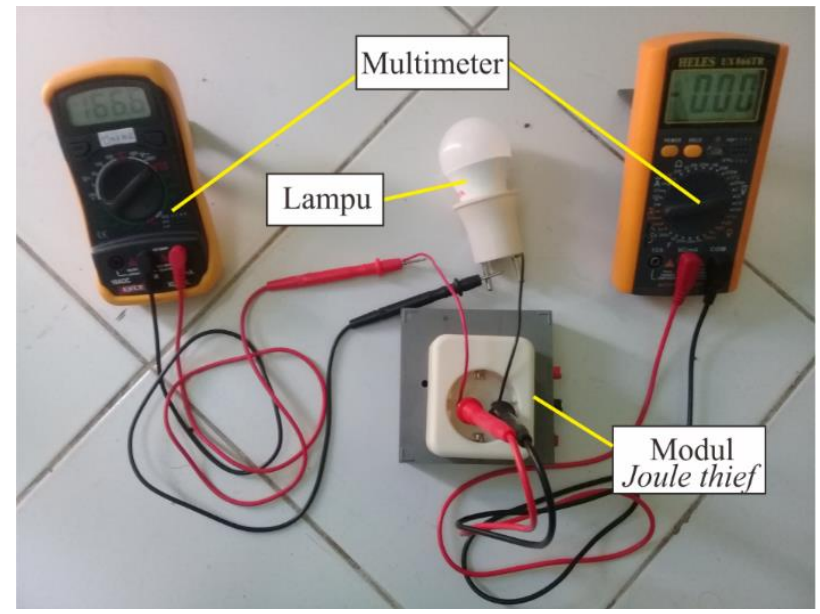

Gambar 18. Pengukuran daya yang dihasilkan modul joule thief

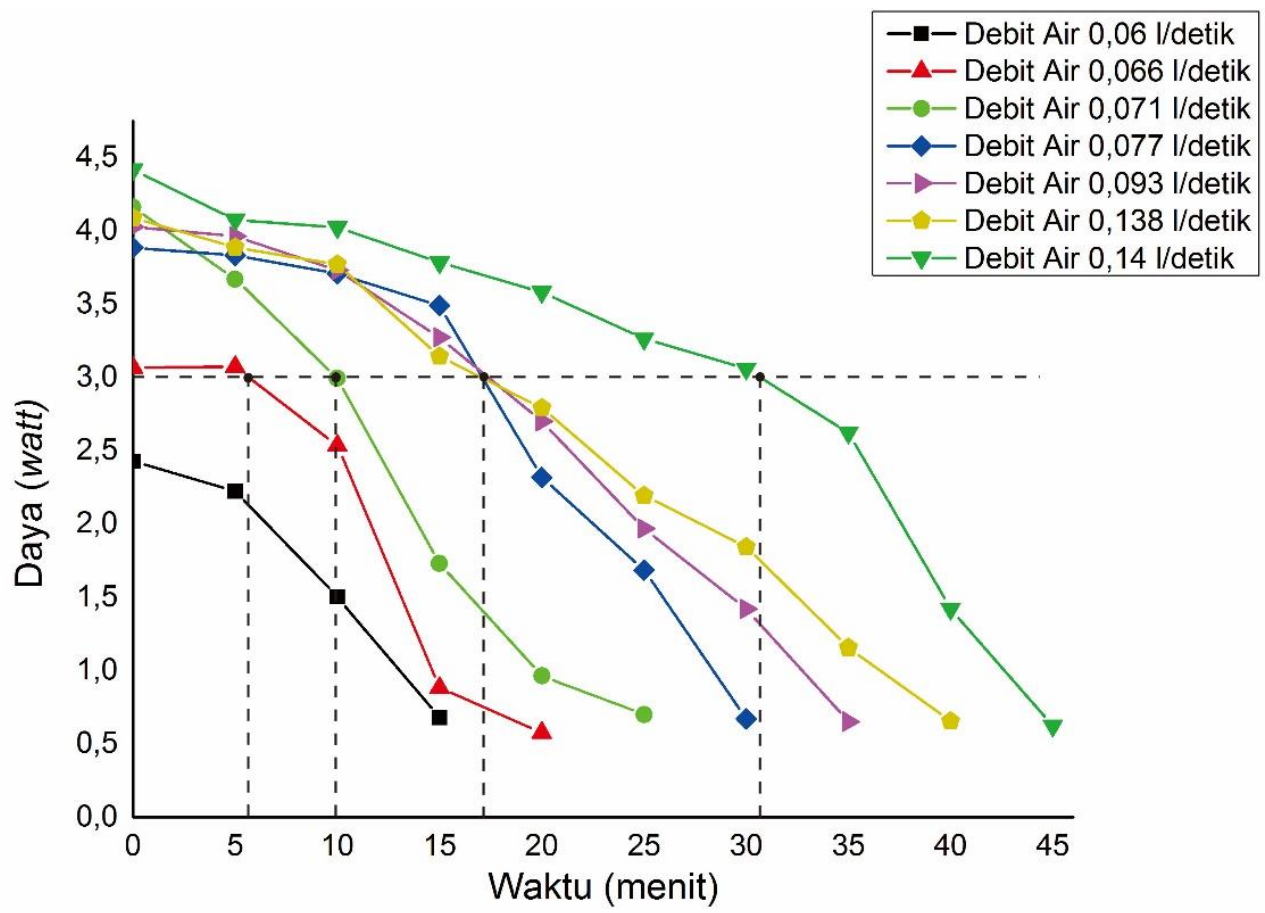

Gambar 19. Grafik daya yang dihasilkan modul joule thief

Gambar 19 merupakan hasil pengukuran daya yang dihasilkan oleh modul joule thief. Daya tersebut diperoleh setelah dilakukan pengisian selama 5 jam pada baterai modul joule thief dengan masing-masing debit air. Daya yang dihasilkan pada pengisian dengan debit air 0,06 liter/detik tidak mencapai batas minimal daya yang dibutuhkan oleh lampu LED sehingga lampu menyala redup. Hal ini terjadi karena arus pengisian yang masuk ke baterai sangat kecil sehingga dengan waktu pengisian yang sama, arus yang tersimpan dalam baterai sangat sedikit. Sedangkan untuk debit air yang lain mengalami kenaikan daya setiap pengisian dengan debit air meningkat. Peningkatan debit air mengakibatkan daya yang masuk dari modul generator semakin besar sehingga mempengaruhi jumlah arus listrik yang tersimpan dalam baterai.Daya yang dihasilka kemudian mengalami penurunan seiring dengan bertambahnya waktu penggunaan untuk menghidupkan lampu LED $3 \mathrm{~W}$ yang berperan sebagai beban.

Untuk mengetahui besar daya maksimal yang dapat dihasilkan oleh modul joule thief, pengukuran dilakukan setelah baterai terisi penuh terlebih dahulu dengan menggunakan debit air maksimal yaitu 0,14 liter/detik. Kemudian dilakukan pengukuran pada output modul joule thief menggunakan multimeter. Hasil pengukuran yang diperoleh ditunjukkan pada Gambar 20. 


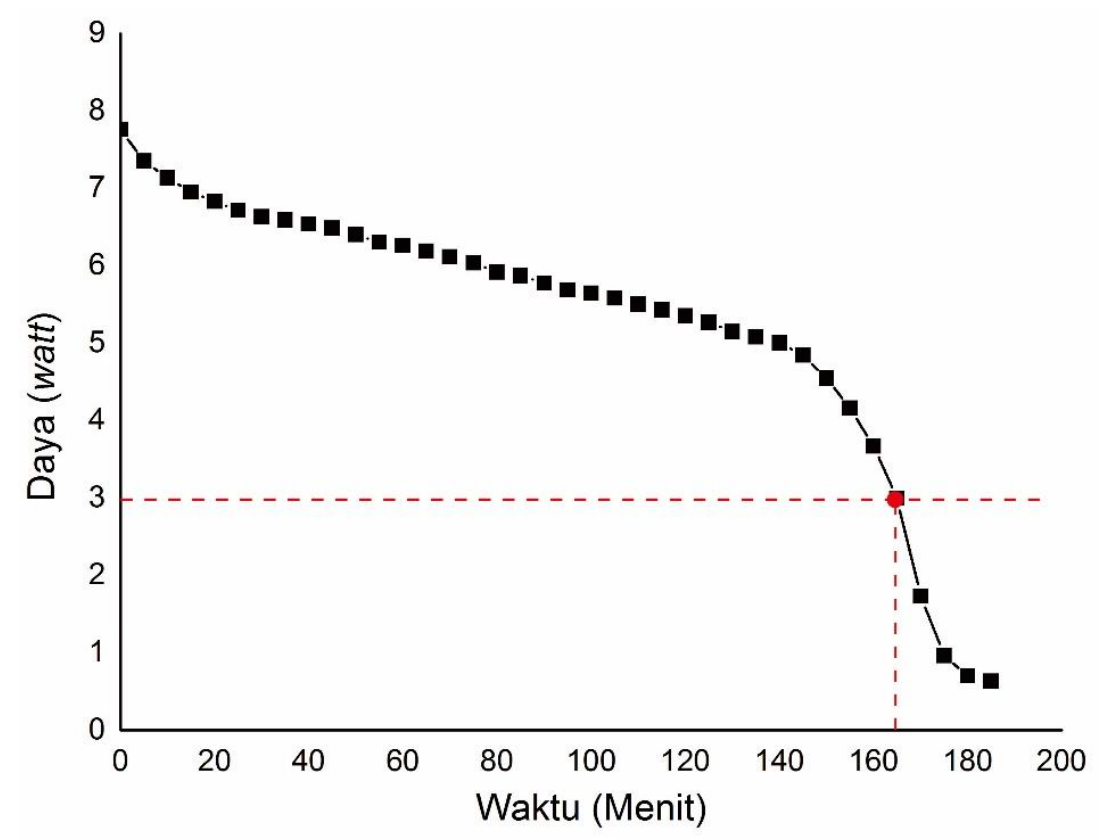

Gambar 20. Grafik daya maksimal yang dihasilkan modul Joule thief

Gambar 20 menunjukkan grafik daya maksimal yang dihasilkan modul joule thief terhadap waktu penggunaan. Daya maksimal yang dihasilkan setelah baterai terisi penuh yaitu sebesar $7,75 \mathrm{~W}$. Ketika pertama kali modul joule thief dihubungkan dengan beban, lampu LED dapat menyala dengan terang. Modul joule thief mampu menyuplai daya yang dibutuhkan lampu LED sebesar $3 \mathrm{~W}$ sampai pada menit ke 165. Pada menit selanjutnya, cahaya lampu perlahan meredup dan cahaya padam pada menit ke 185 yang artinya arus listrik yang tersimpan pada baterai telah habis.

\subsection{Analisis Data Lapangan}

Pengambilan data di lapangan yaitu pengukuran debit air pengunungan yang mengalir ke rumah-rumah warga. Sistem pendistribusian air dari pegunungan menggunakan pipa PVC 1,5 inch sebagai pipa utama dan selang air dengan diameter $3 \mathrm{~cm}$ dipasang untuk tempat mengalirnya air kerumah-rumah warga seperti pada Gambar 21. Pengukuran dilakukan di dalam rumah warga dengan menggunakan botol air mineral $600 \mathrm{ml}$ sebagai penampung air dan stopwatch untuk mengukur waktu pengisian botol air mineral. Pengukuran debit air dilakukan pada 5 titik di wilayah Desa Sumber Agung dengan 3 kali pengulangan setiap titiknya kemudian diambil rata-rata debit air yang mengalir. Hasil pengukuran diperoleh besar debit air rata-rata yang mengalir ke rumah warga yaitu sebesar 0,15 liter/detik.

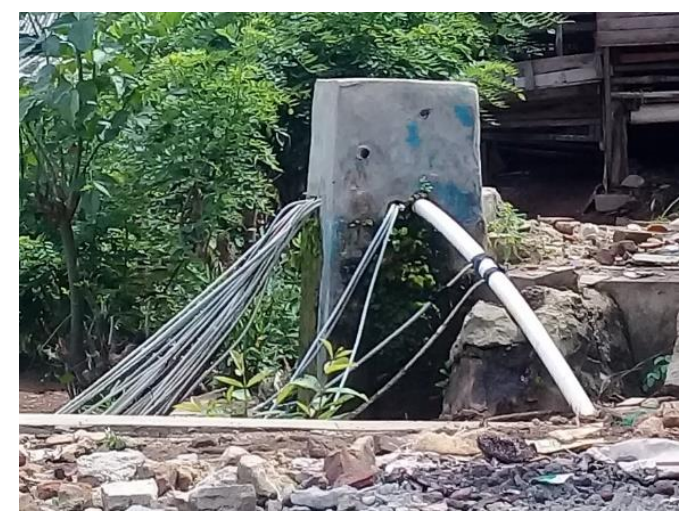

Gambar 21. Sistem distribusi air pegunungan

Modul generator yang telah dibuat dapat menghasilkan listrik dengan tegangan maksimal pada pengujian debit air 0,14 liter/detik. Debit air pengujian lebih kecil jika dibandingkan dengan debit air di lapangan sehingga modul generator ini layak untuk digunakan sebagai sumber energi listrik di Desa Sumber Agung.

\section{Kesimpulan}


Ahmad Badrus Soleh, Amir Supriyanto*, Gurum Ahmad Pauzi, dan Arif Surtono, 2020, Analisis Potensi Energi Listrik Pikohidro dari Sumber Air Pegunungan Serta Upaya Peningkatan Daya Listrik dengan Memanfaatkan Rangkaian Joule Thief, Jurnal of Energy, Material, and Instrumentation Technology, Vol. 1 No. 3, 2020

Berdasarkan hasil pengujian dan pembahasan yang telah dilakukan dapat disimpulkan bahwa pembangkit listrik pikohidro pada penelitian ini telah direalisasikan dalam bentuk modul generator dan modul Joule thief, aliran air pegunungan di Desa Sumber Agung Kecamatan Kemiling Bandarlampung yang mengalir ke rumahrumah warga memiliki potensi untuk pengembangan energi listrik pikohidro dengan tegangan yang dihasilkan berupa tegangan AC dengan daya listrik maksimal yaitu sebesar 7,75 W, tegangan yang dihasilkan modul generator bergantung pada debit air yang digunakan. Semakin besar debit air, tegangan yang dihasilkan akan semakin besar. Tegangan maksimal yang dihasilkan modul generator diperoleh pada debit air 0,14 liter/detik yaitu sebesar $12 \mathrm{~V}$. Tegangan pengisian terbesar yaitu 4,26 V dengan arus pengisian terbesar 23,19 $\mathrm{mA}$.

\section{Daftar Pustaka}

Badan Pusat Statistik. 2017. Proyeksi Penduduk Indonesia (https://www.bps.go.id/publication /2013/10/07/053d25bed2e4d62aab3346ec/proyeksi-penduduk-indonesia-2010-35.html). Diakses pada tanggal 08 Mei 2019.

Erinofiardi, Pritesh Gokhale, Abhijit Date, Aliakbar Akbarzadeh, PutraBismantolo, Ahmad Fauzan Suryono, Afdhal Kurniawan Mainil, Agus Nuramal. 2017. A Review on Micro Hydropower in Indonesia. 1st International Conference on Energy and Power (ICEP). RMIT University. Melbourne. 316-321.

Giancoli, Douglas C. 2001. Fisika Jilid 1 dan 2 (Terjemahan). Erlangga. Jakarta.

Kementrian Energi dan Sumber Daya Mineral. 2017. Statistik Ketenagalistrikan Edisi N0.31 Tahun Anggaran 2018. Direktorat Jenderal Ketenagalistrikan. Jakarta.

Khomsah, A., \& Zuliari, E. A. (2015). Analisa Teori : Performa Turbin Cross Flow Sudu Bambu 5" sebagai Penggerak Mula Generator Induksi 3 Fasa. Seminar Nasional Sains dan Teknologi Terapan III.

Krishnastana, Made Angga Kharisma, Lie Jasa, Antonius Ibi Weking. Studi Analisis Perubahan Debit dan Tekanan Air pada Pemodelan Pembangkit Listrik Tenaga Mikro Hidro. Majalah Ilmiah Teknologi Elektro. Vol. 17. No. 2 .

Manfaluthy, Mauludi. 2018. Pemanfaatan Radiasi Energi Tegangan 150 KV untuk Lampu LED Penerangan Jalan. Jurnal Kajian Ilmu dan Teknologi. Vol. 7. No. 1.

Risnandar, Pratama, F. A., \& Novrinaldi. 2011. GIS untuk Menentukan Potensial Pembangunan Piko-Hidro. Jurnal Teknologi Informasi. 60-61 hlm.

Warsito, Sri Wahyuni, D., Wildan Khoiron. 2011. Realisasi dan Analisa Sumber Energi Baru Tebarukan Nanohidro Dari Aliran Air Berdebit Kecil. Jurnal Material dan Energi Indonesia. Vol. 1. No. 1. Pp 15-21.

Zainuddin, H., Yahaya, M. S., Lazi, J. M., Basar, M. M., \& Ibrahim, Z. 2009. Design and Development of Pico-hydro Generation System for Energy Storage Using Consuming Water Distributed to Houses. International Journal of Electrical, Computer, Energetic, Electronic, and Communication Engineering. Vol. 3. No. 11. 